\title{
Quantification of Iodine in Porous Hydroxyapatite Matrices for Application as Radioactive Sources in Brachytherapy
}

\author{
Kássio André Lacerda ${ }^{1}$, Fernando Soares Lameiras ${ }^{1}$ and Viviane Viana Silva ${ }^{12}$ \\ ${ }^{l}$ Comissão Nacional de Energia Nuclear; Centro de Desenvolvimento da Tecnologia Nuclear; R. Prof. Mário \\ Werneck, s/n; Cidade Universitária; Pampulha; C.P. 941; 30123-970; Belo Horizonte - MG - Brasil. ${ }^{2}$ Universidade \\ Vale do Rio Verde de Três Corações; Av. Castelo Branco, 82; Chácara das Rosas; 37410-000; Três Corações - MG \\ - Brasil
}

\begin{abstract}
In this study, non-radioactive iodine was incorporated in two types of biodegradable hydroxyapatite-based porous matrices (HA and HACL) through impregnation process from sodium iodine aqueous solutions with varying concentrations $(0.5$ and $1.0 \mathrm{~mol} / \mathrm{L})$. The results revealed that both systems presented a high capacity of incorporating iodine into their matrices. The quantity of incorporated iodine was measured through Neutron Activation Analysis (NAA). The porous ceramic matrices based on hydroxyapatite demonstrated a great potential for uses in low dose rate (LDR) brachytherapy.
\end{abstract}

Key words: Hydroxyapatite, brachytherapy, neutron activation analysis (NAA)

\section{INTRODUCTION}

One of the fastest developing areas in biomaterials is the preparation of ceramic matrices based on calcium phosphate aiming at their biocompatibility, physico-chemical, and microstructural and mechanical properties similar to those of hard tissues (Hsu, 2002; Ivanova et al., 2001). Calcium hydroxyapatite (HAp), $\mathrm{Ca}_{10}(\mathrm{PO} 4)_{6}(\mathrm{OH})_{2}$, the main calcium phosphate constituent of bone and tooth tissues, have been investigated targeting their potential application as implant materials (Kinarri \& Gross, 2004; Milev et al., 2003; Silva et al., 2001), controlled drug delivery (Barralet et al., 2004; Itokazu et al., 1998), brachytherapy radioactive sources (IBT Techology Partners, 1997; Nath et al., 1997; Focal Inc., 1997), and tissue engineering (Chen et al., 2004).
One of the applications of the materials is as brachytherapic sources for the treatment of cancer. The code for the practice of medical physics and the clinical procedure of brachytherapy (Nath et al., 1997) deals with the use of small radioactive sources for in situ treatment of cancer in several body sites such as the brain, neck, uterus colon, endometrium, and prostate. The advantages of brachytherapy relative to external beam therapy (teletherapy) are several. The location of the dose in the tumor, the dose gradients around the implant, and the homogeneity of the dose within the tumor are better than those of teletherapy. Contrary to fractionated teletherapy, in low dose brachytherapy (LDR - low-dose rate), radiation is continuously applied for a longer period and the doses are between 0.4 and $0.8 \mathrm{~Gy} / \mathrm{h}$.

In this work, the nuclear analytical technique of neutron activation analysis was used to quantify

\footnotetext{
${ }^{*}$ Author for correspondence
} 
iodine incorporated in hydroxyapatite biodegradable porous matrices for application as radioactive sources in the treatment of cancer tumors by brachytherapy. The quantification of iodine would afford the characterization of the porous matrices for brachytherapy. The values of iodine determined by NAA were used to compare the activity of porous ceramic sources with those of commercial metal seeds used in brachytherapy.

The neutron activation (NA) process consists of exposing a sample to a neutron flux in which the reaction $(\mathrm{n}, \gamma)$ produces a radioactive nuclide (Lieser, 1997). The energy of the radioactive emission allows the identification of the element and the intensity of emission is proportional to the mass of that element. This nuclear method enables to identify and analyze the composition of trace elements in samples of a large variety of materials (Skoog et al., 2002) aiming applications in areas of environmental biotechnology, foods, geology, and material sciences.

\section{MATERIALS AND METHODS}

\section{Hydroxyapatite matrices preparation}

Porous hydroxyapatite matrices were prepared using synthetic and commercial hydroxyapatite powders. The synthetic powder (HA) was obtained by a co-precipitative route (Lacerda, 2005). The commercial powder (HACL) was purchased from Vetec Química Fina Ltda. Both powders were uniaxially pressed in a hydraulic press with floating cylindrical matrix $(\varnothing=8.1 \mathrm{~mm})$ at 100 $\mathrm{MPa}$. The ceramic matrices were sintered in air at $900^{\circ} \mathrm{C}$ for $1 \mathrm{~h}$. The physico-chemical and microstructural characteristics of the powders and ceramic matrices are presented in Table 1 (Lacerda, 2005).

\section{Sodium iodine solutions preparation}

Iodine solutions were prepared in different concentrations, ranging from 0.5 to $1.0 \mathrm{~mol} . \mathrm{L}^{-1}$.

Table 1- Experimental data of synthetic powder (HA) and commercial powder (HACL) matrices

\begin{tabular}{ccccc}
\hline Samples & pPI $\left(\mathbf{g} \cdot \mathbf{m}^{-3}\right)$ & pG $\left(\mathbf{g} \cdot \mathbf{m}^{-\mathbf{3}}\right)$ & $\mathbf{O P}(\boldsymbol{\%})$ & $\mathbf{T P}(\%)$ \\
\hline HA & $1.41 \pm 0.05^{(1)}$ & $1.36 \pm 0.01^{(1)}$ & $53.60 \pm 0.20^{(1)}$ & $55.30 \pm 1.35^{(1)}$ \\
HACL & $1.44 \pm 0.01^{(1)}$ & $1.41 \pm 0.01^{(1)}$ & $52.60 \pm 0.51^{(1)}$ & $54.40 \pm 0.50^{(1)}$ \\
\hline
\end{tabular}

${ }_{\rho} \mathrm{PI}$ - Density, penetration and immersion method; $\rho \mathrm{G}$ - geometric density; OP - Open porosity; TP - Total porosity ${ }^{(1)}$ Confidence level $=95 \%$.

Impregnations solutions were prepared with iodine salt NaI (Riedel De Haen AG Seelze Hanwoven) and deionised water under manual stirring until complete dissolution of the salt. Solution $\mathrm{pH}$ was corrected to 12 with $\mathrm{NaOH}$ (F. Maia Indústria e Comércio Ltda) (Amersham Biosciences Limited, 2002; Intituto de Pesquisa Energéticas e Nucleares, 2005). The remaining solutions were used to incorporate iodine to the ceramic matrices.

\section{Hydroxyapatite matrices impregnation}

The matrices were placed into an oven (FANEM model ORION 515) for $1 \mathrm{~h}$ at $120^{\circ} \mathrm{C}$, followed by cooling under vacuum ranging from $10^{-1}$ to $10^{-2}$ torr for 15 minutes. Next, the dry matrix mass was determined. The matrices were kept under vacuum for $2 \mathrm{~h}$ in an appropriate container until impregnation. Impregnation was carried out by immersing the ceramic matrices into the desired iodine solution. After 2 hours rest in the solution, the masses of the impregnated matrices were determined again.

\section{Irradiation procedure of the impregnated hydroxyapatite matrices}

The TRIGA MARK I IPR-R1 nuclear research reactor located at the CDTN/CNEN (Nuclear Technology Development Centre), Belo Horizonte, was used to irradiate the impregnated matrices. The samples were conditioned in polyethylene tubes and were irradiated with iodine standards. Both samples and iodine standards were irradiated for 5 minutes in the rotary rack facility, at $100 \mathrm{~kW}$, under thermal neutron flux $6.6 \times 10^{11}$ neutrons. $\mathrm{cm}^{-2} \cdot \mathrm{s}^{-1}$. During the irradiation, the following reaction took place:

$$
{ }^{127} \mathrm{I}+\text { neutron } \rightarrow{ }^{128} \mathrm{I}+\text { gamma + beta }
$$

\section{Iodine counting of the irradiated hydroxyapatite matrices}

The induced radioactivity was measured by gamma-ray spectrometry after 2-h decay time. Each sample was counted for 200 seconds using a 
gamma counter system consisted of a HPGe detector (CANBERRA, model GC5019, nominal efficiency $50 \%$ and resolution of $1.9 \mathrm{keV}$ for 1332 $\mathrm{keV}$ of ${ }^{60} \mathrm{Co}$ ). The acquisition and evaluation of the spectra, were performed using the software Genie 2000, CANBERRA. The counting geometry was kept constant for each measurement. The calculation of the iodine concentration was based on ${ }^{128} \mathrm{I}, 25$ - minutes half-life and main $\gamma$-ray 442.9 $\mathrm{keV}(90 \%)$. Linear regression was applied to calculate the iodine concentration in the samples, after correcting the decay time of ${ }^{128} \mathrm{I}$.

\section{RESULTS AND DISCUSSION}

Iodine determination data of hydroxyapatite matrices by NAA are presented in Table 2. Iodine content is given as percentage of weight of the impregnated matrix. The quantity of iodine impregnated into the matrix was high and it varied with the concentration of the NaI solution, the higher the solution concentration, the larger the iodine mass found in the matrices, in accordance with the high open porosity of the matrices (Table 1). Sample iodine mass measured by NAA was converted to percentage $(\% \mathrm{w} / \mathrm{w})$ of impregnated matrix mass (Table 2). The calculated iodine mass was determined through stoichiometric calculations (Table 2).

For a better analysis of the data obtained, iodine mass measured by NAA and determined by stoichiometric calculation in the preparation of the $\mathrm{NaI}$ solution were compared. The comparison of the measured and calculated values are given in Table 2.

Evidenthy 1.0 molar solutions, the variations in NAA- measured and calculated iodine masses was smaller than those of 0.5 molar solutions, thus revealing a larger efficiency of the impregnation processes for more concentrated solutions. Nonradioactive iodine was used in the impregnation process. It was expected that ${ }^{131} \mathrm{I}$ (radioactive) would have the same impregnation behaviour as ${ }^{127} \mathrm{I}$ (stable isotope). Therefore, the same $\mathrm{pH}$ and temperature parameters used by the manufacturer to produce the radioactive sodium iodide (Amersham Biosciences Limited, 2002; Instituto de Pesquisa Energéticas e Nucleares, 2005) were also used.

The manufacturers offer a variety of products with different parameters. The most important parameter is the activity of the solution as it has a direct relation with the dose required in the brachytherapy procedure. This variety of activities has a great importance since they are related to the quantity of solution that may be incorporated into the matrix to obtain the doses wanted in the brachytherapy procedure. The volume impregnated in each matrix was used to estimate the activity of each source when the process was carried out with radioactive solutions (Table 3).

According to Table 3, it was possible to obtain brachytherapy sources with a wide range of activity. HAp matrices offer a very important flexibility, as their activity can be adjusted as required. For comparison sake, we can use ${ }^{125} \mathrm{I}$ solutions with high activity as shown in Table 3. The ceramic matrices impregnated with these solutions might reach up to $60 \mathrm{mCi}$. The commercial sources of ${ }^{125} \mathrm{I}$ present activities in the order of $40 \mathrm{mCi}$ (NATH et al., 1995). Other radionuclides can be tested, mainly those with activities different from that of iodine and with half-life close to that of iodine, such as ${ }^{103} \mathrm{Pd}$, which is also used in brachytherapy (NATH et al., 1995).

Table 2 - Iodine quantification data

\begin{tabular}{lccccccc}
\hline Sample & $\begin{array}{c}\text { Solution NaI } \\
\left(\mathbf{m o l . L}^{-\mathbf{1}}\right)\end{array}$ & $\begin{array}{c}\text { Dry matrix } \\
\text { mass }(\mathbf{g})\end{array}$ & $\begin{array}{c}\text { Impregnated } \\
\text { matrix mass }(\mathbf{g})\end{array}$ & I content (\%) & $\begin{array}{c}\text { Measured I } \\
\text { mass (g) }\end{array}$ & $\begin{array}{c}\text { Calculated I } \\
\text { mass }(\mathbf{g})\end{array}$ & $\begin{array}{c}\text { Comparison } \\
(\%)\end{array}$ \\
\hline HA & 0.5 & 0.2807 & 0.3861 & $2.1 \pm 0.2^{(1)}$ & 0.00788 & 0.00819 & 69.1 \\
HA & 1.0 & 0.2754 & 0.3748 & $3.5 \pm 0.4^{(1)}$ & 0.0128 & 0.0131 & 99.1 \\
HACL & 0.5 & 0.2810 & 0.3799 & $2.1 \pm 0.2^{(1)}$ & 0.00790 & 0.00798 & 72.4 \\
HACL & 1.0 & 0.2758 & 0.3756 & $3.4 \pm 0.3^{(1)}$ & 0.0125 & 0.0128 & 98.9 \\
\hline
\end{tabular}

${ }^{(1)}$ Confidence level $=95 \%$. 
Table 3 - Estimated activity of the brachytherapy sources

\begin{tabular}{|c|c|c|c|c|c|}
\hline Product & Sample & $\begin{array}{c}\text { Sample Mass } \\
\text { (g) }\end{array}$ & $\begin{array}{c}\begin{array}{c}\text { Solution Activity } \\
\left(\text { mCi.mL }^{-1}\right)\end{array} \\
\end{array}$ & $\begin{array}{c}\text { Total Source Activity } \\
(\mathbf{m C i})\end{array}$ & $\begin{array}{c}\text { Activity / Mass } \\
\left(\mathrm{mCi}^{-1} \mathrm{~g}^{-1}\right)\end{array}$ \\
\hline \multirow{4}{*}{${ }^{125} \mathrm{I}-\mathrm{IMS} 30$} & HA 0.5 & 0.3861 & 100 & 10.0400 & 26.0036 \\
\hline & HA 1.0 & 0.3748 & & 9.0690 & 24.1969 \\
\hline & HACL 0.5 & 0.3799 & & 9.4240 & 24.8065 \\
\hline & HACL1.0 & 0.3756 & & 9.0150 & 24.0016 \\
\hline \multirow[t]{4}{*}{ 125 I -IMS300 } & HA 0.5 & 0.3861 & 600 & 60.2400 & 156.0218 \\
\hline & HA 1.0 & 0.3748 & & 54.4140 & 145.1814 \\
\hline & HACL 0.5 & 0.3799 & & 56.5440 & 148.8392 \\
\hline & HACL1.0 & 0.3756 & & 54.0900 & 144.0096 \\
\hline \multirow[t]{4}{*}{${ }^{131}$ I -IBMS3 } & HA 0.5 & 0.3861 & 200 & 20.0800 & 52.0073 \\
\hline & HA 1.0 & 0.3748 & & 18.1380 & 48.3938 \\
\hline & HACL 0.5 & 0.3799 & & 18.8480 & 49.6131 \\
\hline & HACL1.0 & 0.3756 & & 18.0300 & 48.0032 \\
\hline \multirow[t]{4}{*}{${ }^{131}$ I -IBS30 } & HA 0.5 & 0.3861 & 40 & 4.0160 & 10.4015 \\
\hline & HA 1.0 & 0.3748 & & 3.6276 & 9.6788 \\
\hline & HACL 0.5 & 0.3799 & & 3.7696 & 9.9226 \\
\hline & HACL1.0 & 0.3756 & & 3.6060 & 9.6006 \\
\hline \multirow[t]{4}{*}{${ }^{131} \mathrm{I}$-IPEN } & HA 0.5 & 0.3861 & 200 & 20.0800 & 52.0073 \\
\hline & HA 1.0 & 0.3748 & & 18.1380 & 48.3938 \\
\hline & HACL 0.5 & 0.3799 & & 18.8480 & 49.6131 \\
\hline & HACL1.0 & 0.3756 & & 18.0300 & 48.0032 \\
\hline
\end{tabular}

\section{CONCLUSIONS}

HA and HACL matrices displayed characteristics of bioabsorbable hydroxyapatite and crosslinked macro and mesopores with average density in the order of $45 \%$ of the theoretical density, which showed that it is highly porous with total porosity of about $55 \%$ and open porosity around $54 \%$. It was possible to incorporate a sodium iodine aqueous solution to the open pores through an impregnation process, which produced matrices with different quantities of iodine incorporated by varying the concentration of the NaI solution used, and, thus, with varying radioactivities. The use of HAp in the construction of bioabsorbable brachytherapy sources has a great potential due to its flexibility as the matrices present a broad activity range, from low to high (Table 3 ), which facilitates the use of the material.

\section{ACKNOWLEDGEMENTS}

The authors thank the financial support of CNPq and CDTN/CNEN and the collaboration of the Service of Materials and Nuclear Fuel (Nuclear Material and Fuel Laboratory) and the Service for Reactor and Irradiation (Reactor and Neutron Activation Laboratories) both at CDTN.

\section{RESUMO}

Materiais cerâmicos porosos à base de compostos de fosfatos de cálcio (CFC) vêm sendo estudados e desenvolvidos para várias aplicações biomédicas tais como implantes, sistemas para liberação de drogas e fontes radioativas para braquiterapia. Dois tipos de matrizes porosas biodegradáveis de hidroxiapatita (HA e HACL) foram avaliadas em termos da capacidade de incorporação de iodo em suas estruturas. Resultados revelaram que as matrizes porosas a base de hidroxiapatita apresentaram alta capacidade de incorporar iodo em sua estrutura. A quantidade de iodo foi mensurada através da técnica de Análise por Ativação Nêutronica (AAN). As matrizes cerâmicas porosas à base de hidroxiapatita demostraram ter grande potencial para aplicação em braquiterapia de baixa taxa de dose (LDR Low Dose Rate).

\section{REFERENCES}

Amersham Biosciences Limited (2002), Biodirectory 2002. pp. 130, 138, 149. 
Barralet, J.E., Lilley, K.J., Grover, L.M., Farrar, D.F., Ansell, C., Gbureck, U. (2004), Cements from nanocrystalline hydroxyapatite. J Mater Eci Mater Med. 15, 407-411.

Chen, T.M., Wang, H.J., Chen, S.L., Lin, F.H. (2004), Reconstruction of post-traumatic frontal-bone depression using hydroxyapatite cement. Ann Plas Sur, 52, 303-308.

Focal, Inc. Richard D. Leavitt; Luis Avila (1997), Polymeric Delivery of Radionuclides and Radiopharmaceutical, WO 97/33628, 18 Sept. 1997.

Hsu, C.A (2002), Sudy on thermal behavior of uncalcined $\mathrm{Ca}(\mathrm{H} 2 \mathrm{PO} 4)_{2} \cdot \mathrm{H}_{2} \mathrm{O}$ and $\mathrm{CaCO}_{3}$ mixtures. Termochimica, 392-393, 157-161.

IBT Technology Partners, Roy Coniglione; Jonh L. Russel Jr. (1997), Radioisotope dispersed in a matrix brachyterapy, WO 97/19706. 5 jun. 1997.

Intituto de Pesquisa Energéticas e Nucleares (2005), Produtos e Serviços Comercializados Pelo IPEN. São Paulo, available at: <http://www. ipen.br/ipen_p/atendimento/ipen_catalogo_produtos_ servicos. pdf $>$. Accessed in: 09 Mar. 2005.

Itokazu, M., Yang, W., Aoki, T., Ohara, A., Kato, N. (1998), Synthesis of antibiotic-loaded interporous hydroxyapatite blocks by vacuum method and in vitro drug release testing. Biomaterials, 19, 817-819.

Ivanova, T.I., Frank-Kamenetskaya, O.V., Koltsov, A.B., Ugolkov, V.L. (2001), Crystal structure of calcium-deficient carbonated hydroxyapatite. thermal decomposition. J. of Solid Stade Chemistry, 160, 340349.

Kinarri, A.B., Gross. K.A. (2004), Influence of fluorapatite on the properties of thermally sprayed hydroxyapatite coatings. Biomaterials, 25, 49354945.
Lacerda, K.A. (2005), Obtenção de matrizes bioabsorvíveis à base de hidroxiapatita para aplicação em braquiterapia, ScM Dissertation, Nuclear Tecnology Development Centre, Belo Horizonte, Brazil.

Lieser, K. H.(1997), Nuclear and radiochemistry: fundamentals and applications, ed. $\mathrm{VCH}$, Weinheim

Milev, A., Kannangara, G.S.K., Ben-Nissan, B. (2003), Morphological stability of hydroxyapatite precursor, Materials Letter, 57, 1960-1965.

Nath, R, Anderson, L. L., Meli, J. A., Olch, A. J., Stitt J. A., Williamson, J. F. (1997), Code of practice for brachytherapy physics: Report of the AAPM Radiation Therapy Committee Task Group 56. Med Phys, 24(10), 1567-1598.

Nath, R., Anderson, L.L., Luxton, G., Weaver, K. A., Williamson, J. F., Meigooni, A.S. (1995), Dosimetry of interstitial brachytherapy source: Recommendations of the AAPM Radiation Therapy Committee Task Group 43. Med Phys, 22(2), 209234.

Silva, V.V., Lameiras, F.S., Domingues, R.Z. (2001), Microstructural and mechanical study of zirconiahydroxyapatite $(\mathrm{ZH})$ composite ceramic for biomedical applications. Composites Science and Technology, 61, 301-310.

Skoog,. D. A., Holler, F. J., Nieman, T.A. (2002), Princípios de análise instrumental. Translation Caranelli, I., Isolani, P.C., Santos, R. H. A., Francisco, R. H. P., ed. Bookman, Porto Alegre, pp. 714-729. 
PÁGINA

EM

BRANCO 